\title{
Sistem Klasifikasi Tipe Kepribadian dan Penerimaan Teman Sebaya Menggunakan Jaringan Syaraf Tiruan Backpropagation
}

\author{
Yusuf Dwi Santoso $^{1 *}$, Suhartono ${ }^{1}$ \\ ${ }^{1}$ Program Studi Ilmu Komputer/Informatika, Fakultas Sains dan Matematika \\ Universitas Diponegoro \\ ‘Yusufdwisantoso@gmail.com
}

\begin{abstract}
Abstrak
Kepribadian merupakan gambaran tingkah laku dari individu. Penerimaan teman sebaya merupakan penilaian individu bahwa dirinya diterima, didengar, diperhatikan, dihargai, serta dapat merasa aman dan nyaman saat bersama teman-teman dengan umur yang sama. Kepribadian dan penerimaan teman sebaya penting untuk diketahui agar dapat mengenal potensi diri. Tes kepribadian merupakan salah satu sarana untuk mengetahui dan mengklasifikasikan kepribadian seseorang ke tipe kepribadian tertentu. Jaringan syaraf tiruan backpropagation dapat digunakan untuk melakukan klasifikasi sebuah pola berdasarkan permasalahan tertentu seperti halnya dalam mengklasifikasi tipe kepribadian dan penerimaan teman sebaya seseorang. Sistem klasifikasi tipe kepribadian dan penerimaan teman sebaya menggunakan jaringan syaraf tiruan backpropagation dapat digunakan untuk mengklasifikasi tipe kepribadian dan penerimaan teman sebaya seseorang ke dalam beberapa tipe, yaitu introvert diterima, introvert ditolak, ekstrovert diterima, dan ekstrovert ditolak berdasarkan sejumlah set pertanyaan yang menjadi alat ukur dalam penentuan kepribadian. Sistem klasifikasi tipe kepribadian dan penerimaan teman sebaya menggunakan jaringan syaraf tiruan backpropagation menghasilkan arsitektur backpropagation terbaik untuk klasifikasi kepribadian dan penerimaan teman sebaya pada saat menggunakan 1 bidden layer dengan 7 neuron, 10.000 epoch, nilai target error 0.01, dan laju pembelajaran 0.1. Hasil eksperimen jaringan syaraf tiruan backpropagation pada sistem ini menghasilkan rata-rata tingkat akurasi $98.75 \%$ dan tingkat error $1.25 \%$.
\end{abstract}

Kata Kunci: klasifikasi; kepribadian; JST, backpropagation

\section{Pendahuluan}

Remaja adalah sosok yang senantiasa menarik untuk dibicarakan. Ketika seseorang memasuki masa remaja, maka saat itulah ia meninggalkan status dari anak-anak menuju masa dewasa dan ini yang sering disebut sebagai masa peralihan. Ciri-ciri yang menonjol pada usia remaja terlihat dalam perilaku sosialnya [1]. Bagi remaja, penerimaan sosial mempunyai arti penting yang mana salah satunya adalah diterima oleh teman sebaya. Tanpa penerimaan teman sekelompok akan menimbulkan gangguan perkembangan psikis dan sosial remaja. Terdapat beberapa faktor yang mempengaruhi penerimaan teman sebaya, salah satunya yaitu perilaku sosial yang ditampakkan oleh remaja [2].

Perilaku yang ditampakkan individu, tercermin dari gambaran orientasi terhadap dunianya. Orientasi ini disebut dengan sikap, di mana sikap dipengaruhi oleh tipe kepribadian individu. Kepribadian individu, secara sederhana dibedakan menjadi dua kutub berdasarkan arah energi psikis dalam diri individu, yaitu kepribadian ekstrovert dan introvert [3]. Kedua kepribadian ini memiliki caranya masing-masing dalam merespons lingkungannya, sehingga diperlukan sebuah tes yang berguna untuk mengenal kepribadian dan potensi diri yang ada agar dapat dioptimalkan untuk kesuksesan dalam kehidupan sosial.
Tes kepribadian adalah sebuah tes yang dilakukan untuk menentukan tipe kepribadian seseorang [4]. Pengklasifikasian tipe kepribadian yang dilakukan dengan tes kepribadian saat ini sering kali masih menggunakan metode lama dan kurang memanfaatkan teknologi yang ada. Padahal pesatnya perkembangan teknologi memberikan manfaat dalam kehidupan manusia. Pemanfaatan teknologi yang begitu besar membuat komputer dapat bekerja dengan meniru cara kerja otak manusia dengan memanfaatkan metode jaringan syaraf tiruan. Metode tersebut dapat dimanfaatkan untuk mengklasifikasi sebuah pola berdasarkan permasalahan tertentu seperti halnya dalam mengklasifikasikan tipe kepribadian dan penerimaan teman sebaya seseorang. Sehubungan dengan pentingnya pengenalan tipe kepribadian dan penerimaan teman sebaya serta dilatarbelakangi beberapa alasan tersebut maka perlu dibangunnya sebuah sistem klasifikasi tipe kepribadian dan penerimaan teman sebaya yang memanfaatkan teknologi komputer.

Klasifikasi kepribadian telah banyak diaplikasikan pada berbagai jurnal ilmiah. Menurut Lukas, Aribowo, dan Wardhani (2004) proses klasifikasi kepribadian yang menggunakan sistem pakar dengan metode ketidakpastian (uncertainty) ternyata hanya mampu menjawab 10 pertanyaan dari 20 pertanyaan yang ada dengan tingkat kepercayaan yang baik [5]. Klasifikasi 
kepribadian menggunakan jaringan syaraf tiruan learning vector quantization memberikan nilai akurasi sebesar $63.75 \%$ [6]. Dari beberapa penelitian tersebut menunjukkan bahwa metode-metode yang telah digunakan sebelumnya belum memberikan hasil yang maksimal, untuk itu perlu dilakukan penelitian mengenai klasifikasi tipe kepribadian dan penerimaan teman sebaya dengan menggunakan algoritma backpropagation.

Salah satu model jaringan dalam jaringan syaraf tiruan adalah backpropagation. Backpropagation melatih jaringan untuk mendapatkan keseimbangan antara kemampuan jaringan untuk mengenali pola yang digunakan selama pelatihan serta kemampuan jaringan untuk memberikan respons yang benar terhadap pola masukan yang serupa dengan pola yang dipakai selama pelatihan [6]. Sudah banyak penelitian implementasi jaringan syaraf tiruan backpropagation terhadap prediksi seperti prediksi penyakit demam berdarah dengan akurasi 74\% [7] dan kanker serviks dengan akurasi 95.14\% [8].

Beberapa hasil penelitian mengenai algoritma backpropagation sebelumnya menunjukkan bahwa algoritma backpropagation mampu memberikan kinerja yang baik sehingga penulis tertarik untuk membuat sistem klasifikasi tipe kepribadian dengan menggunakan algoritma backpropagation. Backpropagation dapat digunakan untuk klasifikasi karena backpropagation dapat mengenali pola dan memberikan respons benar terhadap pola masukan sehingga cocok untuk mengklasifikasikan kepribadian seseorang berdasarkan input pertanyaan. Sistem klasifikasi kepribadian yang memanfaatkan algoritma backpropagation ini diharapkan mampu memberikan hasil output yang lebih akurat. Sistem klasifikasi kepribadian dan penerimaan teman sebaya ini dibangun berbasis web. Kelebihan pembangunan sistem berbasis web adalah dapat diakses dengan mudah dari jarak jauh melalui browser tanpa harus melakukan instalasi software sehingga nantinya sistem klasifikasi tipe kepribadian dan penerimaan teman sebaya ini dapat digunakan oleh kalangan umum di manapun dan kapanpun tanpa bantuan seorang pakar secara langsung.

Tujuan yang ingin dicapai adalah terciptanya suatu sistem klasifikasi tipe kepribadian dan penerimaan teman sebaya menggunakan jaringan syaraf tiruan backpropagation, sehingga dapat memudahkan seseorang untuk mengenali kepribadiannya masing-masing.

\section{Metode}

\subsection{Pengumpulan Data}

Pada penelitian ini, data diperoleh melalui kuesioner. Kuesioner disebar kepada mahasiswa tingkat satu sampai dengan empat dengan rentang usia 18 sampai 22 tahun melalui google form. Jumlah data yang telah terkumpul sebanyak 210 data kemudian dikelompokkan ke dalam 4 kelas melalui bantuan psikolog, sehingga data sebanyak 210 buah ini terdiri atas 69 data yang didefinisikan ke dalam kelas ekstrovert diterima, 49 data untuk introvert diterima, 52 data untuk ekstrovert ditolak, 40 data untuk introvert ditolak.

\subsection{Arsitektur JST Backpropagation}

Arsitektur JST backpropagation yang digunakan pada sistem ini terdiri atas 3 layer, yaitu input layer, bidden layer, dan output layer.

\subsection{Jaringan Syaraf Tiruan Backpropagation}

Jaringan syaraf tiruan adalah sistem pemroses informasi yang memiliki karakteristik mirip dengan jaringan syaraf biologi. Jaringan syaraf tiruan ditentukan oleh 3 hal, yaitu arsitektur jaringan, metode untuk menentukan bobot penghubung, serta fungsi aktivasi [4].

Backpropagation merupakan salah satu model jaringan syaraf tiruan. Backpropagation melatih jaringan untuk mendapatkan keseimbangan antara kemampuan jaringan untuk mengenali pola yang digunakan selama pelatihan serta kemampuan jaringan untuk memberikan respons yang benar terhadap pola masukan yang serupa tapi tidak sama dengan pola yang dipakai selama pelatihan [8].

Arsitektur backpropagation terdiri atas satu atau lebih unit masukan ditambah satu unit bias, satu layar tersembunyi yang terdiri atas satu atau lebih unit ditambah satu unit bias, serta satu atau lebih unit keluaran.

Algoritma pelatihan backpropagation adalah sebagai berikut:

a. Langkah 0: Inisialisasi semua bobot dengan bilangan acak kecil, epoch $=1$, tentukan laju pembelajaran $(\alpha)$, tentukan jumlah unit pada layar tersembunyi (p) serta tentukan kondisi penghentian. Kondisi penghentian berupa maksimum max epoch dan error target.

b. Langkah 1: Jika epoch $\neq$ max epoch dan error target $<$ MSE, lakukan langkah 2-9.

c. Langkah 2: Untuk setiap pasang data pelatihan (1 sampai dengan $a$ di mana $a$ adalah jumlah data pelatihan), lakukan langkah 3-8.

d. Fase I: Propagasi maju

Langkah 3 : Tiap unit masukan menerima sinyal dan meneruskannya ke unit tersembunyi di atasnya.

Langkah 4 : Hitung semua keluaran di unit tersembunyi $z_{j}(\mathrm{j}=1,2, \ldots, \mathrm{p})$

$$
\begin{aligned}
& z_{-} n e t_{j}=v_{j 0}+\sum_{i=1}^{n} x_{i} v_{j i} \\
& z_{j}=f\left(z_{-}{ }^{n e t_{j}}\right)=\frac{1}{1+e^{-z_{-}{ }^{n e t} j}}
\end{aligned}
$$

Langkah 5: Hitung semua keluaran jaringan di unit $y_{k}$ $(\mathrm{k}=1,2, \ldots, \mathrm{m})$

$$
\begin{aligned}
& y_{-} n e t_{k}=w_{k 0}+\sum_{j=1}^{p} z_{j} w_{k j} \\
& y_{k}=f\left(y_{-} n e t_{k}\right)=\frac{1}{1+e^{-y_{-} n e t_{k}}}
\end{aligned}
$$

e. Fase II : Propagasi mundur

Langkah 6: Hitung faktor $\delta$ unit keluaran berdasarkan kesalahan di setiap unit keluaran $y_{k}(\mathrm{k}=1,2, \ldots, \mathrm{m})$

$$
\delta_{k}=\left(t_{k}-y_{k}\right) f^{\prime}\left(y_{-} n e t_{k}\right)=\left(t_{k}-y_{k}\right) y_{k}\left(1-y_{k}\right)
$$

Hitung suku perubahan bobot $W_{\mathrm{kj}}$ dengan laju percepatan 
$\Delta w_{k j}=\alpha \delta_{k} z_{j}$

$k=1,2, \ldots, m ; j=0,1, \ldots, p$

Langkah 7: Hitung faktor $\delta$ unit tersembunyi berdasarkan kesalahan di tiap unit tersembunyi $z_{j}(j=1,2, \ldots, p)$

$$
\begin{aligned}
& \delta_{-} \text {net }_{j}=\sum_{k=1}^{m} \delta_{k} w_{k j} \\
& \delta_{j}=\delta_{-} \text {net }_{j} f^{\prime}\left(z_{-} \text {net }_{j}\right)=\delta_{-} \text {net }_{j} z_{j}\left(1-z_{j}\right)
\end{aligned}
$$

Hitung suku perubahan bobot $v_{j i}$ dengan laju percepatan

$\Delta v_{j i}=\alpha \delta_{j} x_{i}$

$\mathrm{j}=1,2, \ldots, \mathrm{p} ; \mathrm{i}=0,1, \ldots, \mathrm{n}$

f. Fase III : Perubahan bobot

Langkah 8: Hitung semua perubahan bobot

Perubahan bobot garis yang menuju ke unit keluaran

$w_{k j}($ baru $)=w_{k j}($ sekarang $)+\Delta w_{k j}$

$\mathrm{k}=1,2, \ldots, \mathrm{m} ; \mathrm{j}=0,1, \ldots, \mathrm{p}$

Perubahan bobot garis yang menuju ke unit tersembunyi:

$v_{k j}($ baru $)=v_{k j}\left(\right.$ sekarang $+\Delta v_{j i}$

$\mathrm{j}=1,2, \ldots, p ; \mathrm{i}=0,1, \ldots, \mathrm{n}$

g. Langkah 9: Perbaharui nilai epoch

$$
\text { epoch }=\text { epoch }+1
$$

dan hitung mean squared error (MSE)

$$
M S E=\frac{\sum_{k=1}^{a}\left(t_{k}-y_{k}\right)^{2}}{a}
$$

\subsection{Algoritma Nguyen Widrow}

Bobot awal akan mempengaruhi apakah jaringan mencapai titik minimum lokal atau global dan seberapa cepat konvergensinya. Nguyen dan Widrow (2010) mengusulkan cara membuat inisialisasi bobot ke unit tersembunyi sehinga menghasilkan iterasi yang lebih cepat. Algoritma Nguyen Widrow adalah sebagai berikut [9]:

1. Inisialisasi semua bobot $\left(V_{i j}(\right.$ Lama $\left.)\right)$ dengan bilangan acak dalam interval $[-0.5,0.5]$

2. Hitung:

$$
\left\|v_{j i}\right\|=\sqrt{v_{j 1}^{2}+v_{j 2}^{2}+\ldots+v_{j n}^{2}}
$$

3. Bobot yang digunakan sebagai inisialisasi: $v_{j i}=\frac{\beta v_{j i}(\text { lama })}{\left\|v_{j}\right\|}$

Di mana $\boldsymbol{\beta}$ adalah faktor skala dengan rumus:

$$
\beta=0.7 \sqrt[n]{p}
$$

4. Bobot bias yang dipakai sebagai inisialisasi $\left(v_{j 0}\right)$ adalah bilangan acak dalam interval $[-\beta, \beta]$

\subsection{Preprocessing Data}

Preprocessing data merupakan suatu proses atau langkah yang dilakukan untuk membuat data mentah (dalam penelitian ini berupa data hasil kuesioner) menjadi data yang siap diolah menggunakan metode backpropagation. Pada penelitian ini preprocessing data dilakukan dalam 3 tahapan, yaitu mapping data, normalisasi data, dan pemisahan antara data latih dan data uji dengan metode K-Fold.

Sistem klasifikasi kepribadian ini akan menggunakan sejumlah 10 atribut pertanyaan untuk menentukan tipe kepribadian dan penerimaan teman sebaya seseorang. Setiap hasil tes yang berjumlah 10 atribut pertanyaan ini akan direpresentasikan sebagai variabel input, sedangkan setiap atribut pertanyaan akan direpresentasikan sebagai variabel input. Dari masing-masing atribut pertanyaan tersebut terdapat 4 pilihan jawaban di mana akan merepresentasikan karakteristik dari masing-masing tipe kepribadian.

Langkah mappingdata dilakukanuntuk mengidentifikasi data yang telah diperoleh dalam pengumpulan data ke dalam arsitektur backpropagation. Data yang diperoleh diidentifikasi dan selanjutnya dipetakan data mana yang akan dijadikan imput neuron dan data mana yang akan menjadi output neuron

Langkah kedua yaitu mapping data input dan output jaringan. Pertanyaan dari kuesioner akan menjadi input neuron, pertanyaan ke-1 akan menjadi $\mathrm{x}_{1}$, pertanyaan ke-2 akan menjadi $x_{2}$, begitu seterusnya sampai dengan karakteristik layanan ke 10 akan menjadi $x_{10}$. Sedangkan nilai output neuron diperoleh dari hasil perhitungan sehingga terbentuk arsitektur jaringan dengan 10 neuron input dan 1 neuron output seperti pada Gambar 1.

Langkah ketiga yaitu normalisasi data yang telah dipetakan ke dalam arsitektur jaringan dengan rumus berikut:

$$
x=\frac{r-1}{R-1}
$$

Langkah 4, yaitu identifikasi data latih dan data uji menggunakan K-Fold Cross Validation dengan nilai $\mathrm{K}=$ 10. Data yang telah dilakukan preprocessing kemudian akan diproses menggunakan K-Fold Cross Validation. Tahapan ini dilakukan untuk membagi data hasil menjadi data pelatihan dan data pengujian. Penelitian ini menggunakan dataset sejumlah 160 yang terdiri atas 4 kelas tipe kepribadian. 


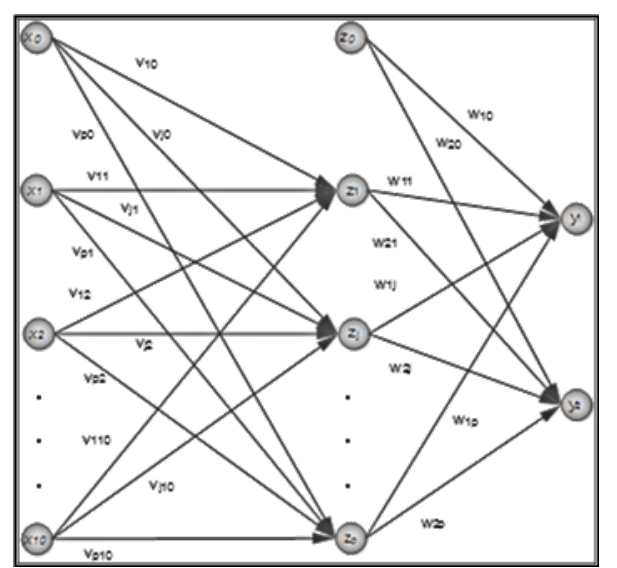

Gambar 1. Arsitektur JST Backpropagation

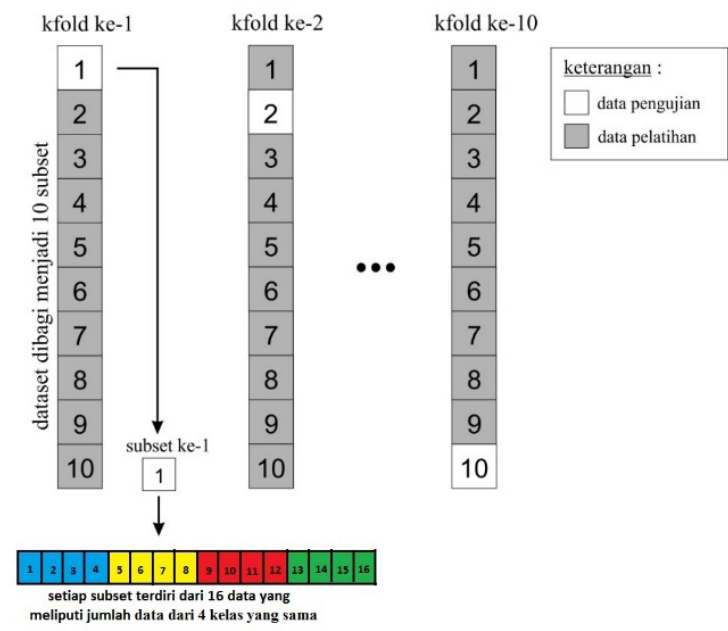

Gambar 2. 10-Fold Cross Validation pada Dataset

Proses K-Fold Cross Validation ini menggunakan nilai, sehingga dataset akan dibagi menjadi 10 subset yang terdiri atas data dengan perbandingan jumlah kelas yang sama. Setiap subset akan terdiri 16 data, di mana 16 data tersebut terdiri atas 4 kelas yang masing-masing terdapat 4 data. Metode ini akan melakukan iterasi sebanyak 10 kali, di mana pada iterasi pertama subset ke-1 menjadi data pengujian, sedangkan sisa subset lainnya akan menjadi data pelatihan. Pada iterasi kedua, subset kedua digunakan sebagai data pengujian dan subset lainnya sebagai data pelatihan, dan seterusnya hingga seluruh subset digunakan sebagai data pelatihan. Penggambaran metode 10-Fold Cross Validation pada dataset lebih jelasnya ditunjukkan pada Gambar 2.

Dataset awal sejumlah 160 dengan proses 10-Fold Cross Validation ini akan diperoleh data pelatihan sebanyak 144 data dan data pengujian sebanyak 16 data dalam setiap pelatihan.

\section{Hasil}

Hasil penelitian berdasar eksperimen nilai target error, eksperimen kombinasi bidden neuron, dan laju pembelajaran.
Tabel 1. Hasil Percobaan Target Error

\begin{tabular}{cll}
\hline $\begin{array}{c}\text { Percobaan } \\
\text { ke- }\end{array}$ & Target Error & Rata-rata MSE \\
\hline & 0.1 & 0.09940154 \\
1 & $\mathbf{0 . 0 1}$ & $\mathbf{0 . 0 4 4 6 7 2 0 2}$ \\
& 0.001 & 0.05989982 \\
& 0.0001 & 0.04645378 \\
& 0.1 & 0.099472963 \\
2 & $\mathbf{0 . 0 1}$ & $\mathbf{0 . 0 5 5 5 7 3 7 4 4}$ \\
& 0.001 & 0.050438866 \\
& 0.0001 & 0.050739845 \\
& 0.1 & 0.099216491 \\
3 & $\mathbf{0 . 0 1}$ & $\mathbf{0 5 0 0 3 2 9 6 3}$ \\
& 0.001 & 0.052557226 \\
& 0.0001 & 0.052302219 \\
\hline
\end{tabular}

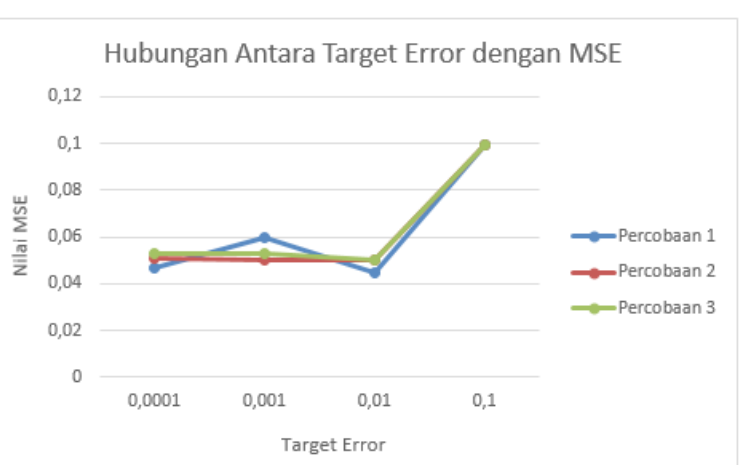

Gambar 3. Grafik Hubungan Target Error dengan MSE

\subsection{Eksperimen Nilai Target Error}

Pengujian target error dilakukan dengan menggunakan nilai target error adalah $0.1 ; 0.01 ; 0.001 ; 0.0001$. Variabel lain yang digunakan pada pengujian ini yaitu jumlah bidden neuron sebanyak 3, laju pembelajaran $(\alpha)$ sebesar 0.4, dan epoch maksimum sebanyak 100.000 epoch. Hasil dari pengujian target error dalam 3 kali percobaan ditunjukkan pada Tabel 1.

Nilai nilai rata-rata mean square error terendah pada ketiga percobaan selalu pada nilai target error 0.01 . Hasil eksperimen pengujian ke-1 ini kemudian disajikan dalam grafik yang dapat dilihat pada Gambar 3

\subsection{Eksperimen Kombinasi Hidden Neuron dan \\ Laju Pembelajaran}

Nilai laju pembelajaran yang diteliti antara 0.1; $0.2 ; 0.3 ; 0.4 ; 0.5 ; 0.6 ; 0.7 ; 0.8 ; 0.9$. Jumlah bidden neuron yang diteliti 2 sampai dengan 9. Nilai maksimum epoch yang digunakan adalah 10.000 dan nilai target error yang digunakan sesuai hasil dari strategi 1 yaitu 0.01. Sehingga akan terbentuk 72 kombinasi parameter penelitian. Masing-masing kombinasi tersebut akan menghasilkan kombinasi jaringan terbaik dari pembangunan sistem ini dengan nilai error minimum 0.01 dan epoch maksimal 10.000 . 


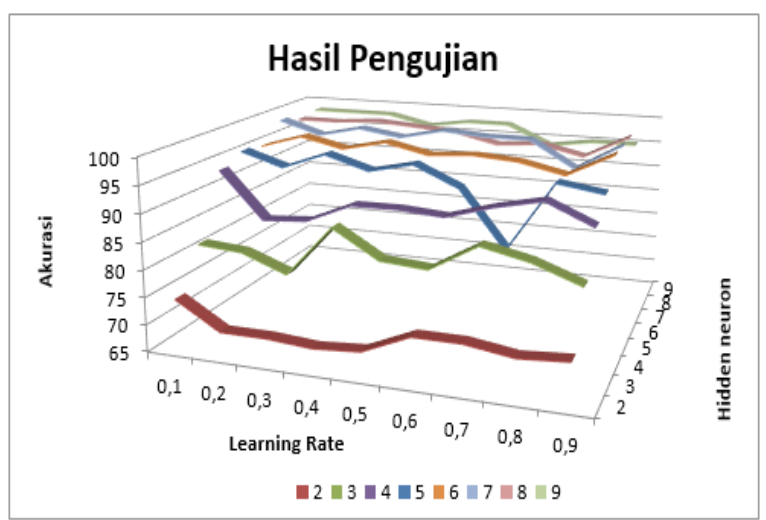

Gambar 4. Grafik Hasil Pengujian

Arsitetur terbaik dari jaringan syaraf tiruan backpropagation didapatkan dari kombinasi laju perubahan dan jumlah bidden neuron. Sesuai dengan hasil penelitian di atas, kombinasi bidden neuron dan alfa yang memiliki tingkat keakuratan tertinggi yaitu pada nilai bidden neuron 7 dan dengan laju percepatan 0,5 dengan tingkat akurasi 98,75\%. Hasil eksperimen pengujian ke-2 ini kemudian disajikan dalam grafik yang dilihat pada Gambar 4.

\section{Diskusi}

Klasifikasi kepribadian telah banyak dipublikasikan pada berbagai jurnal ilmiah. Pada beberapa penelitian terdahulu sepertiLukas, Aribowo, dan Wardhanidisebutkan bahwa proses klasifikasi kepribadian yang menggunakan sistem pakar dengan metode ketidakpastian (uncertainty) ternyata hanya mampu menjawab 10 pertanyaan dari 20 pertanyaan yang ada dengan tingkat kepercayaan yang baik [5]. Klasifikasi kepribadian menggunakan jaringan syaraf tiruan learning vector quantization memberikan nilai akurasi sebesar $63.75 \%$ [6]. Sudah banyak penelitian implementasi jaringan syaraf tiruan backpropagation terhadap prediksi seperti prediksi penyakit demam berdarah dengan akurasi 74\% [7] dan kanker serviks dengan akurasi 95.14\% [8]. Dari beberapa penelitian tersebut menunjukkan bahwa metode-metode yang telah digunakan sebelumnya belum memberikan hasil yang maksimal. Sedangkan penelitian mengenai klasifikasi tipe kepribadian dan penerimaan teman sebaya dengan menggunakan algoritma backpropagation. menghasilkan tingkat akurasi 98.75\%.

\section{Kesimpulan}

Sistem klasifikasi kepribadian dan penerimaan teman sebaya menggunakan jaringan syaraf tiruan backpropagation telah berhasil dibangun dan dapat berjalan sesuai kebutuhan fungsional. Sistem klasifikasi kepribadian dan penerimaan teman sebaya menggunakan jaringan syaraf tiruan backpropagation menghasilkan arsitektur jaringan terbaik dengan 10 neuron pada input layer, 7 neuron pada bidden layer, dan 2 neuron output mampu melakukan klasifikasi dengan tingkat akurasi terbaik, yaitu sebesar $98.75 \%$ dan tingkat error $1.25 \%$.

\section{Daftar Pustaka}

[1] I. Puhar, "Penerimaan Teman Sebaya Pada Remaja Panti Asuhan Ditinjau Dari Kematangan Sosial," Skripsi, Unika Soegijapranata, p. 63, 2007.

[2] R. Sinthia, "Hubungan Antara Penerimaan Sosial Kelompok Kelas dengan Kepercayaan Diri Pada Siswa Kelas I SLTP XXX Jakarta," Triadik, vol. 14, no. 1, p. 42, 2011.

[3] Suryabrata, Psikologi Kepribadian, Jakarta: Rajawali Pers, 2005.

[4] F. Littauer, Personality Plus, Tangerang: Karisma Publishing Group, 2011.

[5] S. Lukas, A. Ariwibowo dan R. Wardhani, "Sistem Pakar Untuk Mendiagnosa Kepribadian Berdasarkan Teori Kepribadian Florence Littauer," Jurnal Ilmiah. Ilmu Komputer, p. 129, 2004.

[6] A. M. Pratiwi dan P. S. Sasongko, "Sistem Klasifikasi Kepribadian Menggunakan Jaringan Syaraf Tiruan," Journal of Informatcs and Technology, p. 8, 2015.

[7] W. Widodo, A. Rachman dan R. Amelia, "Jaringan Syaraf Tiruan Prediksi Penyakit Demam Berdarah dengan Menggunakan Metode Backpropagation,' Jurnal IPTEK, vol. 18, no.1, 2014.

[8] A. T. Susanto, "Aplikasi Diagnosa Kanker Serviks dengan Menggunakan Algoritma Backpropagation," Skripsi, 2012.

[9] J. Siang, Jaringan Syaraf Tiruan dan Pemrograman Menggunakan Matlab, Yogyakarta: Penerbit Andi, 2005. 